\title{
NARROW-GAUGE RAILWAYS IN POLAND AS AN ELEMENT OF REGIONAL TOURISM PRODUCTS
}

\author{
GRAŻYNA ROSA \\ The University of Szczecin, POLAND \\ e-mail: grazyna.rosa@wzieu.pl
}

\author{
\begin{tabular}{l|l} 
RECEIVED & 20 April 2018
\end{tabular} \\ \begin{tabular}{l|l} 
ACCEPTED & 12 July 2018
\end{tabular} \\ JEL \\ CLASSIFICATION \\ L92, R49, Z32, Z33
}

KEYWORDS narrow-gauge railway, tourism product, region

ABSTRACT The article discusses the essence of regional tourism product and its elements. Among them, narrow-gauge railways have been distinguished, as they often constitute a tourist attraction, provide an interesting way of spending free time or learning about monuments and nature, as well as serve as means of transport and a mainstay of railroading's tradition and history.

The aim of the article is to indicate the importance and possibilities to develop passenger service of narrowgauge railways in Poland as an element of regional tourism product. In order to achieve this, desk research method has been applied in respect to available literature and the results of secondary research conducted at the request of the Railway Transport Office and the Central Statistical Office. The analysis covers narrowgauge railways in Poland for the period 2014-2016. The article is of research nature.

\section{Introduction}

Tourism has become a vital element of today's economy. Income generated by this industry is comparable to income achieved in the fuel and advanced technology industries. Tourism industry would not be possible without the worldwide tourism economy scale, involved capital, as well as the number of employees and the complexity of technical processes in transport and hotel management. A tourism product manufactured in this industry (http:// 
www.pwe.com.pl/geografia/produkt_turystyczny,p463872784, access 24.02.2018) is broadly understood also in relation to the region.

An area-related tourism product (Dziedzic, 1988, p. 9) is perceived as tangible and intangible elements that constitute the basis of the tourist's ideas and expectations associated with staying at a given place. According to the concept by V.T.C. Middleton (Zdon-Korzeniowska, 2009, p. 13), a regional tourism product comprises the following factors related to destination: attractions and environment, infrastructure and services, availability, image, and price. In this respect, narrow-gauge railways are part of the area-related tourism product structure, as they are perceived as both an attraction and infrastructure of the destination.

The attractiveness of the narrow-gauge railway results from the fact that it constitutes an interesting form of spending free time and learning about monuments or nature, as well as plays a role of everyday means of transport, and, in many cases, a mainstay of tradition and history of the railroading. Very often, the narrow-gauge railway facilities conceal "rara avis" of railroading, such as historical vehicles and infrastructure. In most cases, it is the railway transport fans who take care of this heritage form and share their knowledge about the history, construction, and purpose of individual objects (Kolej wąskotorowa..., 2017, p. 16).

The aim of the article is to indicate the importance and possibilities to develop passenger service of narrowgauge railways in Poland as an element of regional tourism product. In order to achieve this, desk research method has been applied in respect to available literature and the results of secondary research conducted at the request of the Railway Transport Office and the Central Statistical Office. The analysis covers narrow-gauge railways in Poland for the period 2014-2016. The article is of research nature.

\section{Regional tourism product}

Tourism product, being the subject of supply on the tourism market, has been the subject of analysis of many Polish authors (J. Altkorn, G. Gołembski, B. Meyer, A. Niezgoda, B. Marciszewska, A. Panasiuk, L. Mazurkiewicz, I. Jędrzejczyk, W. Middleton, J. Kaczmarek, A. Stasiak, B. Włodarczyk, M. Zdon-Korzeniowska, P. Zmyślony, W. Middleton) (Niezgoda, 2006, p. 65) has distinguished the general (total) tourism product, which constitutes an idea, expectation, or mental construction that exist in a tourist's mind at the moment of making a travel decision, and which are also based on an idea of the expected time spent at the place of destination. The other product distinguished by Middleton, i.e. a specific product, should be understood as particular goods and services offered to tourists (cf. Meyer, 2015, 238-240). The differences between tourist products offered by entrepreneurs and regions were presented by L. Mazurkiewicz (Mazurkiewicz, 1999, p. 83), who analyses the tourist product on a micro and macro scale. A tourist product on a micro scale is defined as all services and tangible goods offered to a single tourist in the scope of tourist reception, whereas on a macro scale, a tourist product includes services and tangible goods offered to all tourists in the tourist reception scope (Meyer, 2015, p. 239). This product is most often defined as a bundle of tangible and intangible elements that enable accomplishment of a trip (Marciszewska, 2010, p. 42).

Tourism products may be divided into simple and complex products (Meyer, 2015, p. 239). The simple products are individual services (e.g. hotel, restaurant or guide services) or items (e.g. maps and tourist guides, tourist equipment), whereas complex products consist of a larger or smaller number of simple products that satisfy basic needs, which relate to the implementation of the trip, and needs that accompany the main need (the reason for the trip), which form a coherent whole (e.g. a tourist event or a tourist destinations) (Kaczmarek, Stasiak, Włodarczyk, 2010 , p. 186). Although such package should contain at least transport and accommodation, it usually also includes 
other services, such as transfer, tour leader assistance, car rental, travel and sightseeing services (Meyer, 2006, pp. 69-70). Tourism product is therefore a service in nature, which implies features such as complementarity, complexity, intangibility, production unity, exchange and consumption processes, no possibility to produce for stock, store, and seasonality (Gołembski, 2009, p. 71).

It is a spatially determined product that includes an internally complex set of elements distinguished for its specific location in space (Meyer, 2004, pp. 180-181). These elements are of a diversified character, as they consist of different levels of tourist area product, which include (Kaczmarek, Stasiak, Włodarczyk, 2002, p. 103):

- heritage, including all elements created as a result of natural processes and human activities, such as the natural environment, culture and tradition, which form the basis for running various types of activities and the functioning of an area,

- infrastructure, including elements created as a result of human activity that is aimed at tourism development, such as tourist and paratourism accommodation or regional events,

- added value, including the attributes of the area that bring satisfaction to tourists, such as the idea or image,

- organization and management, that is, all elements that enable operation of single elements in the form of a coherent whole constituting the tourist area product.

Tourism product of the area of tourist reception (also described as an area's tourist product or tourist area product) arises on many levels and consists of various elements that ultimately should form a coherent whole that is attractive to tourists (Meyer, 2015, p. 239). According to this definition, narrow-gauge railways can be both the attraction of the area and an element of its infrastructure, as well as its added value.

\section{Narpow-gauge pailways in Poland}

The origins of narrow-gauge railways in Poland date back to the 19th century. Narrow gauge railway had for a long time played an important complementary role to standard gauge railway. Even in the second half of the twentieth century, it was used both in the scheduled service of passenger traffic and in the transport of goods over short distances. Its advantages, such as the relatively low cost of construction and use of infrastructure, allowed it to be used, among others, in places where the use of standard-gauge infrastructure and rolling stock was unprofitable. Nowadays, narrow gauge railway is only occasionally used for goods transport. This is mainly due to the intensive development of individual and public road transport. Moreover, its purpose has changed, as it is now used as a tourist attraction that is a part of a given regional tourism product.

In the years 2014-2016, 23 narrow-gauge railways operated in twelve Polish voivodships. Its infrastructure varies significantly due to the historical background of every line. In the years 2014-2016, the total length of the railways amounted to $649 \mathrm{~km}$, of which nearly $395 \mathrm{~km}$ were exploited in 2016. Significantly smaller length of railways used results most often from the poor technical condition of infrastructure that prevents the use of old routes. The largest number of narrow-gauge railways is located in Mazowieckie voivodship (over $105 \mathrm{~km}$ ), with only $33 \mathrm{~km}$ of them exploited in 2016. In 2016, the longest active infrastructure (over $30 \mathrm{~km}$ ) were in the possession of (Kolej wąskotorowa..., 2017, p. 10):

1. Przeworska Narrow-Gauge Railway - $46 \mathrm{~km}$. The journey takes place among the landscapes of Rzeszowszczyzna with the route running, among others, through 602 meters of the only Polish tunnel for narrow-gauge railway in Szklary. 
2. Żuławska Narrow-Gauge Railway - $36 \mathrm{~km}$. The railways includes three fragments of routes, which run among the most beautiful tourist areas of Żuławy Wiślane and the Vistula Spit.

3. Bieszczadzka Forest Railway $-33 \mathrm{~km}$. This route leads through picturesque terrains of Bieszczady.

As previously mentioned, the modern narrow-gauge railway most often constitutes a tourist attraction and cultural heritage that provides the opportunity to travel by exceptional historical rolling stock through places that present special natural and historical values. Statistical data confirms its importance in the Polish tourist landscape. Narrow-gauge railways, which possess a safety certificate issued by the President of the Office of Rail Transport, transport more and more people, mainly for tourist purposes. The number of passengers on these railways increased from 761 thousand in 2015, to almost 948 thousand in 2016 (Kolej wąskotorowa..., 2017, p. 2),

This means that tourists are beginning to appreciate the values of narrow-gauge railways, which often become an additional tourist attraction of a given region, and thus a part of its tourism product. The increasing popularity of narrow-gauge railways also brings additional benefits, as it allows obtaining funds for their maintenance and ensuring an adequate level of services. In many cases, the actions that guarantee compliance with the above standards require financial support for railway operations that come from public funds, as well as funding for the implementation of projects under the European Funds or the Swiss-Polish Cooperation Program.

Figure 1 shows the increase in the popularity of narrow-gauge railways in Poland, measured by the number of transported passengers per voivodships.

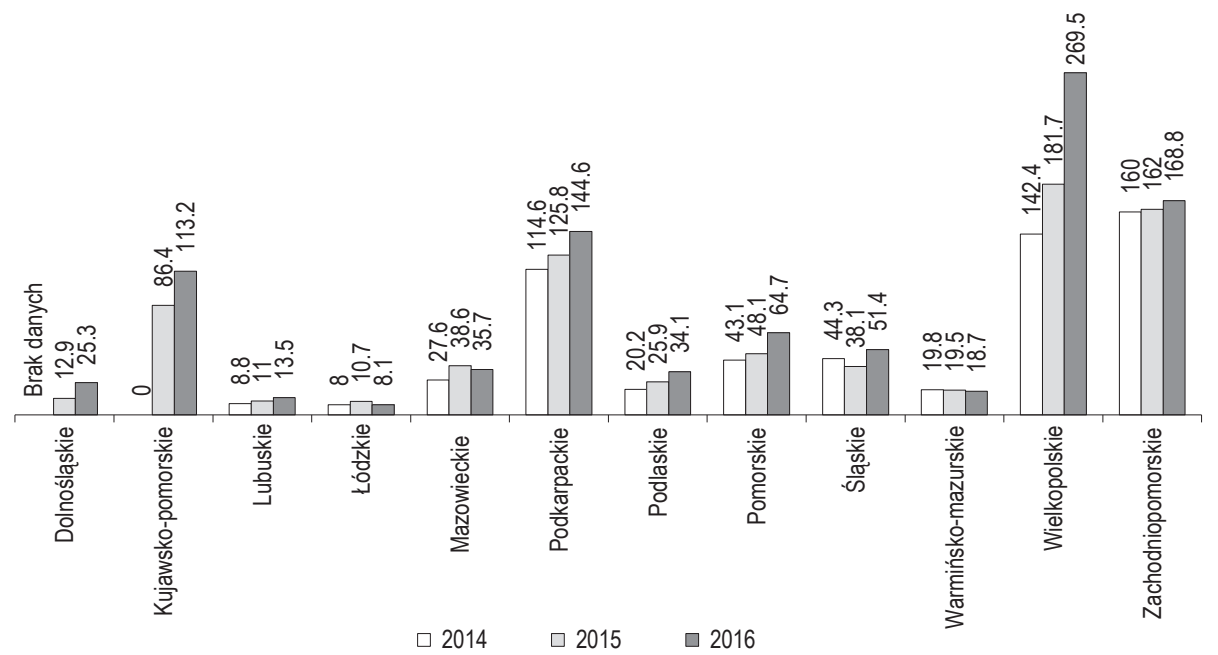

Figure 1. Number of passengers (in thousands) in the years 2014-2016 per voivodships

Source: Kolej wąskotorowa... (2017), p. 5.

In 2016, the six biggest barrow-gauge railways transported almost $3 / 4$ of passengers. Among popular railways can be found those, whose main advantage is natural conditions, namely Seaside Narrow-Gauge Railway (Rewal), Bieszczadzka Forest Railway, Żuławska Suburban Railway, as well as a narrow-gauge railway that constitutes a city attraction, i.e., the Park Railway Maltanka, Pleszewska Narrow-Gauge Railway that resumed its operation in 2015. 
The largest number of trains were launched by railways in Wielkopolskie, Zachodniopomorskie, Ślaskie and Podkarpackie voivodships. The number of trains in Wielkopolskie voivodship results from the operation of the Park Railway Maltanka, which is a city attraction dedicated to children, and regular connections offered every day by Pleszewska Narrow-Gauge Railway. In Podkarpackie and Zachodniopomorskie voivodships, the biggest number of trains are launched in the summer season, when the tourist traffic, and thus a large number of travellers, can be observed, as shown in Figure 2.

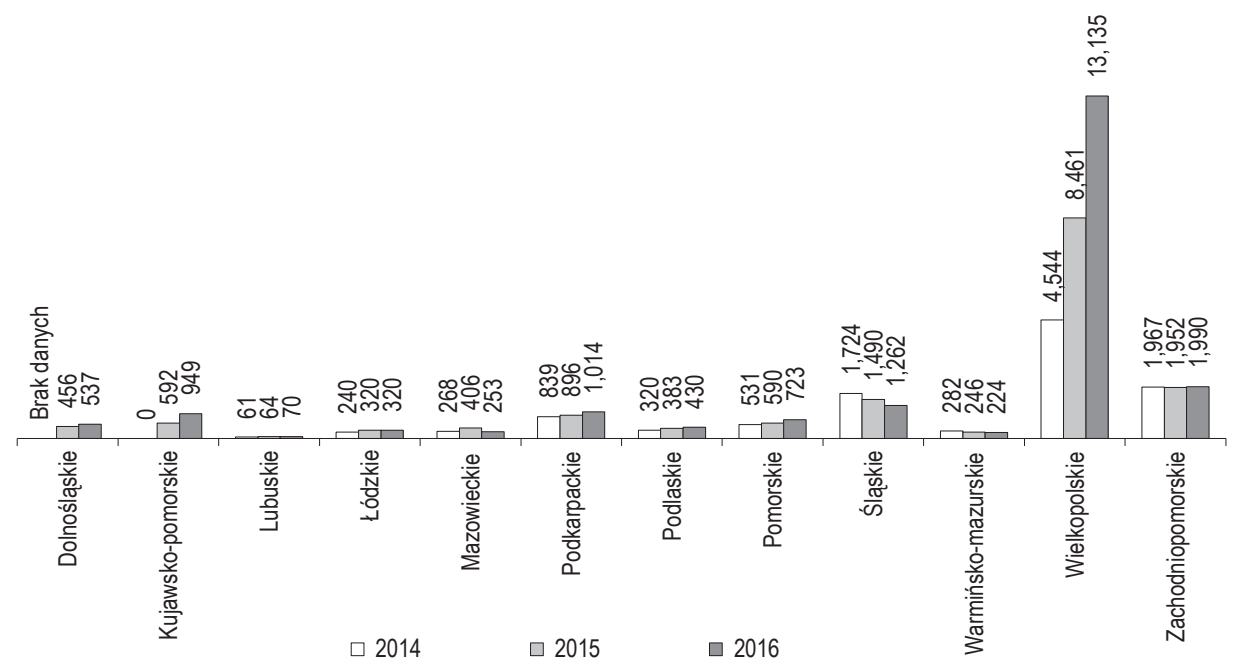

Figure 2. The number of trains launched in the years 2014-2016 per voivodships

Source: Kolej wąskotorowa... (2017), p. 7.

A characteristic feature of narrow gauge railways is their considerable diversification, among others, in terms of route length. In 2016, the most exploited narrow-gauge railways were located in Wielkopolskie, Zachodniopomorskie and Podkarpackie voivodships. The ratio of the exploitation index to the number of trains running is important due to the costs incurred by the organizers of narrow-gauge railways when running longer routes. Railways that offer transport on longer routes run a relatively low number of trains compared to those that offer transport on routes up to several kilometres. This is noticeable, among others, when comparing Wielkopolskie and Podkarpackie voivodships. The costs of their operation are related to, inter alia, maintenance of narrow-gauge railway infrastructure, vehicles and technical facilities as well as employees' remuneration.

\section{Conclusions}

The increased popularity of narrow-gauge railways among tourists corresponds with the general increase in popularity of railways among passengers, especially those travelling for tourist reasons. However, in many cases, the number of passengers using narrow-gauge railways is too small to guarantee funds for the proper maintenance of infrastructure and vehicles. The existence of narrow-gauge railways depends on the sources of additional 
financing. Therefore, local associations and government authorities support the maintenance of tourist narrowgauge railways. Most often, these funds simply allow them to function.

Therefore, the future of narrow-gauge railways still depends on small and irregular subsidies. On the other hand, the interest in railway heritage, including steam traction and old devices related to railway traffic, is growing. The rarer these objects become, the more interest they arouse.

On the basis of these considerations, it can be stated that narrow-gauge railway may be developed best when it complements and integrates the tourist offer while simultaneously satisfying the demand for transport services, which, in turn, makes it an integral element of the regional tourism product.

\section{References}

Altkorn, J. (1994). Marketing in Tourism. Warszawa: Wydawnictwo Naukowe PWN.

Dziedzic, E. (1988). Obszar recepcji turystycznej jako przedmiot zarządzania turystycznego. Monografie i Opracowania nr 442. Warszawa: SGH.

Gołembski, G. (ed.) (2009). Kompendium wiedzy o turystyce. Warszawa: Wydawnictwo Naukowe PWN.

Kaczmarek, J. (2005). Produkt turystyczny. Pomysł. Organizacja. Zarządzanie. Warszawa: Polskie Wydawnictwo Ekonomiczne.

Kaczmarek, J., Stasiak, A., Włodarczyk, B. (2002). Produkt turystyczny albo jak organizować poznanie świata. Łódź: Wydawnictwo Uniwersytetu Łódzkiego.

Kaczmarek, J., Stasiak, A., Włodarczyk, B. (2010). Produkt turystyczny. Pomysł - organizacja - zarządzanie. Warszawa: PWE.

Kolej wasskotorowa w Polsce. Dane rynkowe oraz zasady funkcjonowania, bezpieczeństwo, ochrona dziedzictwa kolei (2017). Warszawa: Urząd Transportu Kolejowego.

Marciszewska, B. (2010). Produkt turystyczny a ekonomia doświadczeń. Warszawa: C.H. Beck.

Mazurkiewicz, L. (1999). Produkt turystyczny w ujęciu marketingu terytorialnego. In: K. Pieńkos (ed.), Konkurencyjność produktu turystycznego. Warszawa: Wyższa Szkoła Ekonomiczna.

Meyer B. (ed.) (2006). Obsługa ruchu turystycznego. Warszawa: Wydawnictwo Naukowe PWN.

Meyer, B. (2015). Konsument na rynku usług turystycznych. In: G. Rosa (ed.), Konsument na rynku usług. Warszawa: C.H. Beck.

Niezgoda, A. (2006). Obszar recepcji turystycznej w warunkach rozwoju zrównoważonego. Poznań: Wydawnictwo Akademii Ekonomicznej w Poznaniu.

Pieńkos, K. (ed.) (1999). Konkurencyjność produktu turystycznego. Warszawa: Wyższa Szkoła Ekonomiczna.

Rosa, G. (eds.) (2015). Konsument na rynku usług. Warszawa: C.H. Beck.

Zdon-Korzeniowska, M. (2009). Jak kształtować regionalne produkty turystyczne? Teoria i praktyka. Kraków: Wydawnictwa Uniwersytetu Jagiellońskiego.

Zmyślony, P. (2008). Partnerstwo i przywództwo w regionie turystycznym. Poznań: Wydawnictwo Akademii Ekonomicznej.

Zmyślony, P., Niezgoda, A. (2003). Popyt turystyczny. Uwarunkowania i perspektywy rozwoju. Poznań: Wydawnictwo Akademii Ekonomicznej.

Cite this article aS: Rosa, G. (2018). Narrow-gauge railways in Poland as an element of regional tourism products. European Journal of Service Management, 3 (27/1), 241-246. DOI: 10.18276/ejsm.2018.27/1-30. 